\title{
Relationship between Lipolysis and Calcium in Epididymal Adipose Tissue of Obese-Hyperglycaemic Mice
}

\author{
J. P. Dehaye, J. Winand, P. Poloczek, and J. Christophe \\ Department of Biochemistry, Medical School, U. L. B., Brussels, Belgium
}

Summary. In the epididymal adipose tissue of lean $(+/+)$ C57 BL/6J mice deprived of calcium by ethyleneglycol-bis- $\left(\beta\right.$-aminoethylether) $\mathrm{N}, \mathrm{N}^{\prime}$-tetraacetic acid (EGTA) treatment, corticotrophin-(1-24)tetracosapeptide (ACTH)-stimulated lipolysis was abolished and peak levels of adenosine $3^{\prime}, 5^{\prime}$-cyclic monophosphate (cyclic $\mathrm{AMP}^{1}$ ) were reduced by $80 \%$. Calcium omission was less effective on isoproterenol-stimulated lipolysis and was ineffective on theophylline- or dibutyryl cyclic AMP-stimulated lipolysis. All EGTA effects were reversible. Lipolytic agents stimulated the net uptake of ${ }^{45} \mathrm{Ca}$. This effect was inhibited by 2,4-dinitrophenol. The ${ }^{45} \mathrm{Ca}$ accumulated in response to lipolytic agents was largely $\mathrm{La}^{3+}$-nondisplaceable and was released with a half-life of 13 minutes under EGTA treatment. These results suggest that the mechanism promoting ${ }^{45} \mathrm{Ca}$ uptake in response to lipolytic agents was beyond cyclic AMP production in the adipose tissue of lean mice, but independent of free fatty acid release. In turn, intracellular as well as extracellular calcium facilitated maximal rates of lipolysis.

In the adipose tissue of obese-hyperglycaemic (ob/ob) mice, the response to the lipolytic agents of glycerol release and cyclic AMP levels was reduced by $65 \%$ and ${ }^{45} \mathrm{Ca}$ uptake was not stimulated. A $1-2$ hour preincubation of adipose tissue increased markedly the effect upon lipolysis and ${ }^{45} \mathrm{Ca}$ uptake, but not that of peak cyclic AMP levels of isoproterenol. It is concluded that the adipose tissue of ob/ob mice displayed a reversible impairment of ${ }^{45} \mathrm{Ca}$ uptake in response to lipolytic agents.

1 List of abbreviations: cyclic AMP: adenosine $3^{\prime}, 5^{\prime}$-cyclic monophosphate; ACTH: corticotrophin-(1-24)-tetracosapeptide; 2,4-DNP: 2,4-dinitrophenol; HEPES: N-2-hydroxyethylpiperazine- $\mathrm{N}^{\prime}$-2-ethanesulfonic acid; EGTA: ethyleneglycolbis-( $\beta$-aminoethylether $) \mathrm{N}, \mathrm{N}^{\prime}$-tetraacetic acid; ob/ob: obesehyperglycaemic
Key words: Obese-hyperglycaemic mice, adipose tissue, lipolysis, calcium uptake, cyclic AMP, isoproterenol, ACTH-(1-24), theophylline.

Lipolytic hormones act upon adipose tissue via cyclic AMP and phosphorylation of hormone sensitive lipase [1]. ACTH at low concentration, however, can evoke a lipolytic response which is not accompanied by an increase in cyclic AMP levels [2,3]. A group of antilipolytic agents, including $\alpha$-adrenoceptor blocking agents, the tricyclic anti-depressant dibenzazepin, sulphonylurea drugs, the biguanide phenformin, local anaesthetics, and divalent cations interfering with calcium are able to inhibit hormone-stimulated lipolysis without decreasing cyclic AMP levels [4-6]. These observations support the suggestion that calcium, as well as cyclic AMP, is involved in the lipolytic process [7-11]. We have therefore studied the causal relationship between lipolysis and calcium movements in the adipose tissue of normal mice.

In the adipose tissue of ob/ob mice, previous data indicate in vitro defects in glycerol release [3] and adenylate cyclase activity $[12,13]$. In the present work, we studied the effects of isoproterenol on calcium movements in the adipose tissue of ob/ob mice. A preliminary account of this work has appeared [14].

\section{Materials and Methods}

Male lean homozygous $(+/+)$ and obese-hyperglycaemic (ob/ob) mice from our C57 BL/6J colony [4] were three to four months old at time of sacrifice and were fed ad libitum unless stated otherwise.

Theophylline, dibutyryl cyclic AMP, isoproterenol, inulin, ATP and lyophilized firefly lantern extracts were obtained from Sigma Chemical Co. (St. Louis, Mo., U.S.A.); bovine serum albu- 
Table 1. Effects of isoproterenol, ACTH, theophylline and dibutyryl cyclic AMP on glycerol release by adipose tissue of lean and obesehyperglycaemic mice in the presence or in the absence of $2.5 \times 10^{-3} \mathrm{~mol} / \mathrm{l}$ calcium in the incubation medium

\begin{tabular}{|c|c|c|c|c|c|}
\hline \multirow[t]{2}{*}{ Additions } & \multirow{2}{*}{$\begin{array}{l}\text { Concentration } \\
\mathrm{mol} / \mathrm{l}\end{array}$} & \multicolumn{2}{|l|}{ Lean mice } & \multicolumn{2}{|c|}{ Obese-hyperglycaemic mice } \\
\hline & & $\mathrm{Ca}+$ & $\mathrm{Ca} 0$ & $\mathrm{Ca}+$ & $\mathrm{Ca} 0$ \\
\hline None & & $0.33 \pm 0.04$ & $0.23 \pm 0.02^{\mathrm{a}}$ & $0.08 \pm 0.01$ & $0.08 \pm 0.01$ \\
\hline Isoproterenol & $10^{-7}$ & $0.53 \pm 0.06$ & $0.33 \pm 0.08^{a}$ & $0.10 \pm 0.01$ & $0.06 \pm 0.03$ \\
\hline Isoproterenol & $5 \times 10^{-7}$ & $0.85 \pm 0.03$ & $0.46 \pm 0.05^{a}$ & $0.18 \pm 0.05$ & $0.08 \pm 0.04$ \\
\hline Isoproterenol & $2.5 \times 10^{-6}$ & $1.14 \pm 0.09$ & $0.93 \pm 0.11^{\mathrm{a}}$ & $0.44 \pm 0.11$ & $0.22 \pm 0.05^{\mathrm{a}}$ \\
\hline Isoproterenol & $10^{-5}$ & $1.49 \pm 0.12$ & $1.01 \pm 0.05^{\mathrm{a}}$ & $0.62 \pm 0.08$ & $0.47 \pm 0.05^{\mathrm{a}}$ \\
\hline ACTH & $10^{-5}$ & $1.53 \pm 0.13$ & $0.28 \pm 0.07^{\mathrm{a}}$ & $0.67 \pm 0.05$ & $0.10 \pm 0.03^{\mathrm{a}}$ \\
\hline Theophylline & $5 \times 10^{-3}$ & $1.49 \pm 0.14$ & $1.29 \pm 0.09$ & $0.63 \pm 0.06$ & $0.51 \pm 0.04$ \\
\hline Dibutyryl cyclic AMP & $5 \times 10^{-3}$ & $1.31 \pm 0.10$ & $1.27 \pm 0.15$ & $0.72 \pm 0.04$ & $0.71 \pm 0.05$ \\
\hline
\end{tabular}

Epididymal adipose tissue fragments were preincubated for $30 \mathrm{~min}$ in Krebs-Ringer bicarbonate buffer with $2.5 \times 10^{-3} \mathrm{~mol} / 1 \mathrm{CaCl} \mathrm{l}_{2}$ and $4 \mathrm{~g} / 100 \mathrm{ml}(\mathrm{w} / \mathrm{v})$ albumin. They were then transferred into a medium of identical composition or to a medium without calcium but with $2 \times$ $10^{-3} \mathrm{~mol} / 1$ EGTA. Results are expressed as $\mu \mathrm{mol}$ glycerol $/ 100 \mathrm{mg}$ fresh tissue $/ 90 \mathrm{~min}$ and are means of 5 experiments $\pm \mathrm{SEM}$. ${ }^{\mathrm{a}} \mathrm{p}<0.05$ compared with $\mathrm{Ca}+$

min (Fraction V, fatty acid poor) from Pentex (Miles Research Co., Kankakee, Ill., U.S.A.), and glycerol-3-phosphate dehydrogenase and glycerol kinase from Boehringer (Mannheim, FRG). ACTH (synthetic corticotrophin (1-24)-tetracosapeptide) was a gift from Ciba-Geigy Ltd. (Basel, Switzerland). Cyclic $\left[8-{ }^{3} \mathbf{H}\right]$ AMP $(27 \mathrm{Ci} / \mathrm{mmol}),\left[{ }^{3} \mathrm{H}\right]$-inulin and ${ }^{45} \mathrm{CaCl}_{2}$ were obtained from the Radiochemical Centre (Amersham, England). Lumasolve and Lumagel were from Lumac Systems A. G. (Basel, Switzerland)

In each experiment, the epididymal fat pads from six lean and two obese mice were cut in $20 \mathrm{mg}$ fragments. Incubation techniques and the assays of glycerol in the medium and of cyclic AMP in the tissue were as previously described $[3,15,16]$.

For ATP determination, the fragments were frozen at $-70^{\circ} \mathrm{C}$ in $1 \mathrm{~mol} / 1$ perchloric acid. After ultrasonication the homogenates were centrifuged and ATP was determined in the aqueous phase according to the luciferin-luciferase method of Bihler and Jeanrenaud [17]. ATP standards were prepared daily in $1 \mathrm{~mol} / 1$ perchloric acid.

To allow the measurement of the net uptake of calcium, the tissue fragments were exposed at $37^{\circ} \mathrm{C}$ to a Krebs-Rinsw! hicarbonate medium ( $\mathrm{pH} 7.4)$ containing ${ }^{45} \mathrm{CaCl}_{2}(1 \mu \mathrm{Ci} / \mathrm{ml})$ and $\left[{ }^{3} \mathrm{H}\right]$ inulin $(0.1 \mathrm{mg} / \mathrm{ml} ; 1 \mu \mathrm{Ci} / \mathrm{ml})$. At the end of the incubation, the fragments were blotted lightly and dissolved in $2 \mathrm{ml}$ Lumasolve (4 hours at $50^{\circ} \mathrm{C}$ ).

Radioactivity was assayed in adipose tissue by dual radioisotope counting in $12 \mathrm{ml}$ of a scintillation medium $(5.5 \mathrm{~g}$ Permablend III (Packard Instrument Co., Downers Grove, Ill., U.S.A.) in 11 toluene) with a Packard 2450 Tri-Carb liquid spectrometer. Aliquots of the media were counted in $12 \mathrm{ml}$ Lumagel. Quench corrections were applied by means of an external standard and the net uptake of calcium was corrected for ${ }^{45} \mathrm{Ca}$ present in the interstitial space available to $\left[{ }^{3} \mathrm{H}\right]$-inulin:

$$
\begin{aligned}
& \text { Net uptake of }{ }^{45} \mathrm{Ca}=\frac{\left(\mathrm{Ca}_{\mathrm{T}}-\mathrm{H}_{\mathrm{T}} \times \frac{\mathrm{Ca}_{\mathrm{M}}}{\mathrm{H}_{\mathrm{M}}}\right) \times 100}{\text { s.a. } \times \text { fresh wt }} \text { in nmol/ } \\
& 100 \mathrm{mg} \\
& \text { where } \mathrm{Ca}_{\mathrm{T}}=\text { total dpm of }{ }^{45} \mathrm{Ca} ; \mathrm{H}_{\mathrm{T}}=\text { total dpm of }\left[{ }^{3} \mathrm{H}\right] ; \frac{\mathrm{Ca}_{\mathrm{M}}}{\mathrm{H}_{\mathrm{M}}}=
\end{aligned}
$$

ratio of dpm of ${ }^{45} \mathrm{Ca}$ to $\mathrm{dpm}$ of ${ }^{3} \mathrm{H}$ in the medium; s. a. $=$ specific radioactivity of calcium in the medium; and fresh $w t=$ tissue fresh weight in $\mathrm{mg}$.

The lanthanum-wash technique was used to determine the proportion of total calcium accumulated which could be con- sidered as "superficial" $[18,19]$. After a 15 or 60 min preincubation, in the absence or presence of $10^{-5} \mathrm{~mol} / 1$ isoproterenol, the tissue fragments were rinsed for 15 minutes at $37^{\circ} \mathrm{C}$ in a Hepes medium ( $\mathrm{pH} \mathrm{7.4)} \mathrm{containing} 2 \times 10^{-3} \mathrm{~mol} / 1 \mathrm{LaCl}_{3}$. The ${ }^{45} \mathrm{Ca}$ content of the fragments was determined as above.

Calcium efflux was measured on tissue fragments prelabelled for $60 \mathrm{~min}$ with ${ }^{45} \mathrm{Ca}(1 \mu \mathrm{Ci} / \mathrm{ml})$ and $\left[{ }^{3} \mathrm{H}\right]$-inulin $(0.1 \mathrm{mg} / \mathrm{ml} ; 1 \mu \mathrm{Ci} /$ $\mathrm{ml})$ in the presence or in the absence of $10^{-5} \mathrm{~mol} / \mathrm{l}$ isoproterenol, rinsed for $1 \mathrm{~min}$ at $37^{\circ} \mathrm{C}$ with fresh medium, then transferred at $10 \mathrm{~min}$ intervals to a series of vials containing $2 \mathrm{ml}$ of calcium-free Krebs-Ringer bicarbonate buffer ( $\mathrm{pH} 7.4$ ) with $4 \mathrm{~g} / 100 \mathrm{ml}$ albu$\min$ and $2 \times 10^{-3} \mathrm{~mol} / 1$ EGTA. The sum of radioactivity in each wash plus the radioactivity remaining in the fragments at the end of the efflux period was taken to represent the total initial radioactivity.

Results are given \pm SEM and significance $(p<0.05)$ assessed with Student's test for grouped or ungrouped data.

\section{Results}

\section{Lean Mice}

Effects of Extracellular Calcium on in Vitro Lipolysis, Cyclic AMP and ATP. Constant rates of glycerol release from adipose tissue fragments were observed for at least 90 minutes in experiments conducted in the presence of $2.5 \times 10^{-3} \mathrm{~mol} / 1$ calcium under basal conditions as well as in the presence of $2.5 \times 10^{-6}$ $\mathrm{mol} / \mathrm{l}$ isoproterenol or with $10^{-3} \mathrm{~mol} / 1$ theophylline (Fig. 1). The two lipolytic agents increased lipolysis 4-5 fold. Maximally effective concentrations [3] of isoproterenol, ACTH, and dibutyryl cyclic AMP stimulated the release of glycerol 4 to 5 -fold (Table 1).

In a calcium-free medium containing $2 \times$ $10^{-3} \mathrm{~mol} / 1$ EGTA the lipolytic response to $10^{-5} \mathrm{~mol} / 1$ ACTH was abolished, and the response to $10^{-5} \mathrm{~mol} / \mathrm{l}$ isoproterenol reduced by $40 \%$, but the lipolytic response to $5 \times 10^{-3} \mathrm{~mol} / 1$ theophylline or $5 \times 10^{-3}$ $\mathrm{mol} / 1$ dibutyryl cyclic AMP was not altered (Table 1 ). 

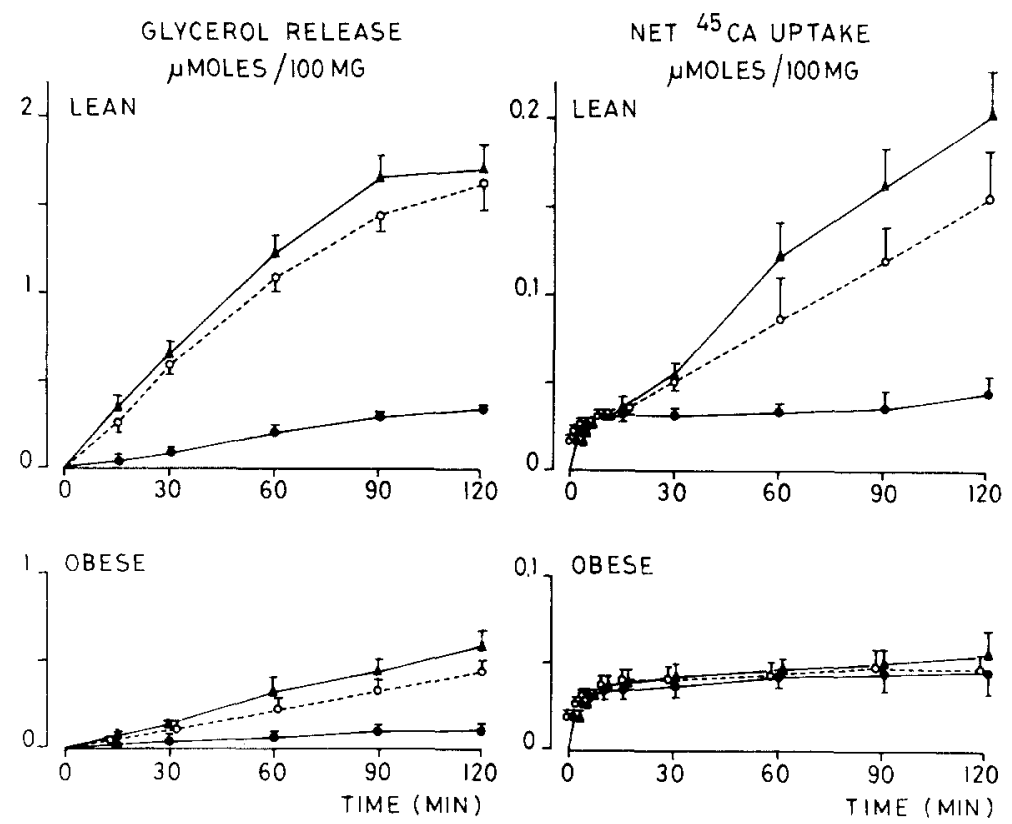

Fig. 1. Effects of $2.5 \times 10^{-6} \mathrm{~mol} / 1$ isoproterenol $(\mathrm{O})$ and $10^{-3} \mathrm{~mol} / 1$ theophylline $(\boldsymbol{A})$ on the time course of glycerol release (left panels) and net ${ }^{45} \mathrm{Ca}$ uptake in excess of $\left[{ }^{3} \mathrm{H}\right]$-inulin space (right panels) in epididymal adipose tissue of 3-4 month old normal (upper panels) and obese-hyperglycaemic (lower panels) mice. Adipose tissue fragments were preincubated for $30 \mathrm{~min}$ with $2.5 \times 10^{-3} \mathrm{~mol} / 1$ calcium and incubated without $(\bullet)$ or with isoproterenol $(O)$ or theophylline $(\boldsymbol{A})$. Values are means \pm SEM of 7 experiments

Table 2. Reversibility of calcium deprivation on lipolysis, cyclic AMP levels, and ATP levels in the epididymal adipose tissue from normal mice. Epididymal adipose tissue fragments were preincubated for $30 \mathrm{~min}$ in calcium-free Krebs-Ringer bicarbonate buffer containing $2 \times 10^{-3} \mathrm{~mol} / \mathrm{l}$ EGTA. They were then incubated in the same medium $(0 \rightarrow 0)$ or in a medium without EGTA but with 2.5 $\times 10^{-3} \mathrm{~mol} / \mathrm{l}$ calcium $(0 \rightarrow+)$. Controls were preincubated and incubated in the presence of $2.5 \mathrm{~mol} / 1$ calcium throughout $(+\rightarrow$ $+)$

\begin{tabular}{lccc}
\hline Conditions & Basal & $\begin{array}{l}\text { Isoproterenol } \\
10^{-5} \mathrm{~mol} / 1\end{array}$ & $\begin{array}{l}\mathrm{ACTH} \\
10^{-5} \mathrm{~mol} / 1\end{array}$ \\
\hline $\begin{array}{l}\mathrm{A} / \text { Lipolysis } \\
+\rightarrow+\end{array}$ & & & \\
$0 \rightarrow 0$ & $0.24 \pm 0.05$ & $1.08 \pm 0.09$ & $1.22 \pm 0.10$ \\
$0 \rightarrow+$ & $0.10 \pm 0.03^{\mathrm{a}}$ & $0.89 \pm 0.07^{\mathrm{a}}$ & $0.08 \pm 0.03^{\mathrm{a}}$ \\
$\mathrm{B} /$ Cyclic AMP levels & $0.18 \pm 0.03$ & $1.08 \pm 0.10$ & $0.93 \pm 0.10^{\mathrm{a}}$ \\
$+\rightarrow+$ & & & \\
$0 \rightarrow 0$ & $22 \pm 4$ & $301 \pm 28$ & $445 \pm 57$ \\
$0 \rightarrow+$ & $19 \pm 4$ & $253 \pm 27$ & $87 \pm 13^{\mathrm{a}}$ \\
$\mathrm{C} /$ ATP levels & $25 \pm 5$ & $265 \pm 30$ & $283 \pm 32^{\mathrm{a}}$ \\
$+\rightarrow+$ & & & \\
$0 \rightarrow 0$ & $10.5 \pm 1.2$ & $6.3 \pm 0.8$ & $4.3 \pm 0.6$ \\
$0 \rightarrow+$ & $9.6 \pm 1.1$ & $9.2 \pm 1.1$ & $7.4 \pm 0.9^{\mathrm{a}}$ \\
& $10.2 \pm 1.1$ & $5.2 \pm 0.7$ & $3.6 \pm 0.5$ \\
\hline
\end{tabular}

A/ Glycerol release was assayed after a $60 \mathrm{~min}$ incubation and expressed as $\mu \mathrm{mol} / 100 \mathrm{mg}$ fresh tissue/60 min. B/ Cyclic AMP measurements were performed after a $7 \mathrm{~min}$ incubation and expressed as $\mathrm{pmol} / 100 \mathrm{mg}$ fresh tissue. $10^{-3} \mathrm{~mol} / 1$ theophylline was present during the preincubation and the incubation periods. In the absence of theophylline, basal cyclic AMP contents were $7 \pm 2$ $\mathrm{pmol} / 100 \mathrm{mg}$. C/ ATP content in the tissue were assayed after a 60 min incubation and expressed as $\mathrm{nmol} / 100 \mathrm{mg}$ fresh tissue. Results are means of 4 experiments \pm SEM. ${ }^{a} \mathrm{p}<0.05$ compared with control $(+\rightarrow+)$ data
Cyclic AMP levels were determined after a $7 \mathrm{~min}$ exposure to ACTH or isoproterenol, i. e. at a time of maximal elevation of cyclic AMP in tissue fragments preincubated for $30 \mathrm{~min}$ with $10^{-3} \mathrm{~mol} / 1$ theophylline [4]. In the presence of $2.5 \times 10^{-3} \mathrm{~mol} / 1 \mathrm{calcium}$ and with $10^{-3} \mathrm{~mol} / 1$ theophylline alone, the peak concentration of cyclic AMP was increased 3-fold over the control value; this concentration increased 14- and 20 -fold, respectively, when $10^{-5} \mathrm{~mol} / 1$ isoproterenol or $10^{-5} \mathrm{~mol} / 1 \mathrm{ACTH}$ were added in combination with $10^{-3} \mathrm{~mol} / \mathrm{l}$ theophylline (Table 2).

After a 30 minute period of calcium deprivation in the presence of $10^{-3} \mathrm{~mol} / 1$ theophylline, the basal levels of cyclic AMP were unaffected (Table 2). There was a dramatic decrease $(-80 \%)$ in the peak elevation of cyclic AMP in response to $10^{-5} \mathrm{~mol} / 1$ $\mathrm{ACTH}$ and a non-significant $(-17 \%)$ reduction in the presence of $10^{-5} \mathrm{~mol} / \mathrm{l}$ isoproterenol.

The tissue content of ATP was halved after a 60 minute exposure to $10^{-5} \mathrm{~mol} / 1 \mathrm{ACTH}$ or to $10^{-5} \mathrm{~mol} / 1$ isoproterenol in a normal medium (Table 2). In a medium in which calcium was omitted, the fall in ATP in response to the lipolytic hormones was lowered $(-23 \%$ vs $-59 \%$ with $\mathrm{ACTH}$, and $-4 \%$ vs $40 \%$ with isoproterenol: Table 2 ).

These effects of calcium depletion on lipolysis, and on the levels of cyclic AMP and ATP were reversible. After a 30 minute preincubation period in the presence of $2 \times 10^{-3} \mathrm{~mol} / 1$ EGTA, and relative to tissue fragments remaining in EGTA, the reintroduction of calcium increased the basal lipolytic rate such that over the next 60 minutes control values 

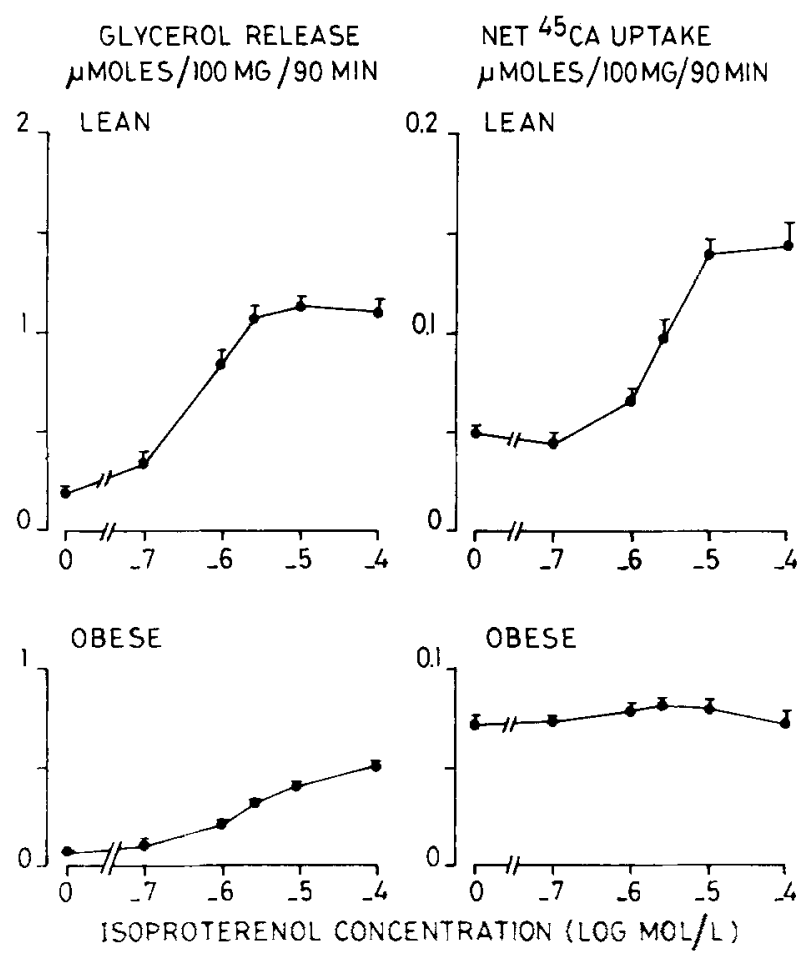

Fig. 2. Dose-response curves of isoproterenol on glycerol release (left panels) and net ${ }^{45} \mathrm{Ca}$ uptake (right panels) in epididymal adipose tissue of 3-4 month old normal (upper panels) and obesehyperglycaemic (lower panels) mice. Medium glycerol and ${ }^{45} \mathrm{Ca}$ uptake in excess of $\left[{ }^{3} \mathrm{H}\right]$-inulin space were assayed after $90 \mathrm{~min}$ incubations. Values are means \pm SEM of 6 experiments

were almost attained (Table 2). Under the same conditions, the ACTH-stimulated lipolysis was again almost fully restored upon reintroduction of calcium. With isoproterenol, the $18 \%$ elevation of lipolysis noted after calcium reintroduction corresponded to a normal rate of lipolysis (Table 2).

Peak levels of cyclic AMP tested after a 7 minute exposure to lipolytic hormones in the presence of calcium and following a 30 minute calcium deprivation in the presence of $10^{-3} \mathrm{~mol} / \mathrm{l}$ theophylline showed at least partial restoration (Table 2): with $10^{-5} \mathrm{~mol} / \mathrm{l} \mathrm{ACTH}$ the rise in cyclic AMP levels was 3.3-fold higher than in the continuous absence of calcium and corresponded to $64 \%$ of the levels observed in tissue fragments incubated in the uninterrupted presence of calcium; with $10^{-5} \mathrm{~mol} / \mathrm{l}$ isoproterenol the elevation of cyclic AMP was normal.

The levels of ATP were again markedly affected by $10^{-5} \mathrm{~mol} / 1$ ACTH or $10^{-5} \mathrm{~mol} / 1$ isoproterenol treatment $(-65 \%$ and $-49 \%$, respectively, Table 2).

Calcium Movements and Lipolysis. The basal net uptake of ${ }^{45} \mathrm{Ca}$ tested at a $2.5 \times 10^{-3} \mathrm{~mol} / 1$ extracel-
Table 3. Effects of isoproterenol on total ${ }^{45} \mathrm{Ca}$ uptake and on $\mathrm{La}^{3+}$-nondisplaceable ${ }^{45} \mathrm{Ca}$ after 15 or 60 minute incubation of adipose tissue from lean and obese-hyperglycaemic mice

\begin{tabular}{|c|c|c|c|c|}
\hline \multirow[t]{2}{*}{ Incubation time } & \multicolumn{2}{|c|}{ Lean mice } & \multicolumn{2}{|c|}{$\begin{array}{l}\text { Obese-hyper- } \\
\text { glycaemic mice }\end{array}$} \\
\hline & $15 \min$ & $60 \min$ & $15 \min$ & $60 \mathrm{~min}$ \\
\hline \multicolumn{5}{|l|}{ Without $\mathrm{La}^{3+}$ wash } \\
\hline $\begin{array}{l}\text { Control } \\
\text { Isoproterenol }\end{array}$ & $27 \pm 4$ & $39 \pm 5$ & $34 \pm 5$ & $43 \pm 5$ \\
\hline $10^{-5} \mathrm{~mol} / \mathrm{I}$ & $29 \pm 4$ & $121 \pm 14^{a}$ & $36 \pm 6$ & $44 \pm 5$ \\
\hline \multicolumn{5}{|l|}{ With $\mathrm{La}^{3+}$ wash } \\
\hline $\begin{array}{l}\text { Control } \\
\text { Isoproterenol }\end{array}$ & $3 \pm 1$ & $15 \pm 2$ & $4 \pm 2$ & $15 \pm 3$ \\
\hline $10^{-5} \mathrm{~mol} / \mathrm{l}$ & $12 \pm 3^{a}$ & $59 \pm 7^{\text {a }}$ & $4 \pm 2$ & $16 \pm 3$ \\
\hline
\end{tabular}

Epididymal adipose tissue fragments were preincubated for $30 \mathrm{~min}$ and then incubated for 15 or $60 \mathrm{~min}$ in the presence of ${ }^{45} \mathrm{Ca}$ and $\left[{ }^{3} \mathrm{H}\right]$-inulin as described under Materials and Methods. The $\mathrm{La}^{3+}$ washing was conducted for $15 \mathrm{~min}$ in a medium containing $10^{-2} \mathrm{~mol} / 1 \mathrm{HEPES}, 140 \times 10^{-3} \mathrm{~mol} / 1 \mathrm{NaCl}, 0.5 \times 10^{-3} \mathrm{~mol} / \mathrm{l}$ $\mathrm{MgCl}_{2}, 6 \times 10^{-3} \mathrm{~mol} / 1 \mathrm{KCl}, 2 \times 10^{-3} \mathrm{~mol} / 1 \mathrm{LaCl}_{3}$, and $4 \mathrm{~g} / 100 \mathrm{ml}$

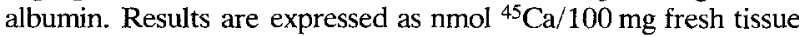
and are means of 4 experiments \pm SEM. ${ }^{a} p<0.05$ compared with control data

lular calcium concentration (Fig. 1) proceeded with an initial rapid phase of approximately 10 minutes duration (half-time 1-2 minutes) followed by a slower net uptake extending over 110 minutes. The first rapid phase of ${ }^{45} \mathrm{Ca}$ accumulation corresponded to about $70 \%$ of total ${ }^{45} \mathrm{Ca}$ accumulated. This phase was not significantly different in the presence of $10^{-5} \mathrm{~mol} / 1$ isoproterenol or $5 \times 10^{-3} \mathrm{~mol} / 1$ theophylline, but a sustained accumulation of ${ }^{45} \mathrm{Ca}$ followed after 15 minutes so that the net uptake of ${ }^{45} \mathrm{Ca}$ was 3-5 times higher after 90 minutes than in the absence of lipolytic agents (Fig. 1). Half-maximal effects of isoproterenol on the net uptake of ${ }^{45} \mathrm{Ca}$ and glycerol release occurred at approximately $3 \times 10^{-6} \mathrm{~mol} / 1$ and $10^{-6} \mathrm{~mol} / 1$, respectively (Fig. 2).

Under basal conditions, the ${ }^{45} \mathrm{Ca}$ insensitive to $\mathrm{La}^{3+}$-washing represented $12 \%$ and $39 \%$ of the total ${ }^{45} \mathrm{Ca}$ accumulated after 15 minutes and 60 minutes, respectively. When $10^{-5} \mathrm{~mol} / \mathrm{l}$ isoproterenol was present during the loading period, the proportion of ${ }^{45} \mathrm{Ca}$ accumulated that did not respond to the wash technique increased to $40 \%$ and $48 \%$, respectively, after 15 and 60 minutes of incubation (Table 3). A 3.7fold increase in the $\mathrm{La}^{3+}$ nondisplaceable ${ }^{45} \mathrm{Ca}$ could already be detected within 15 minutes of incubation with isoproterenol.

Maximally effective concentrations of the other lipolytic agents $\mathrm{ACTH}$, theophylline and dibutyryl cyclic AMP induced a stimulation of net ${ }^{45} \mathrm{Ca}$ uptake comparable to that obtained with $10^{-5} \mathrm{~mol} / 1$ isoproterenol (Table 4). 
Table 4. Effects of isoproterenol, ACTH, theophylline and dibutyryl cyclic AMP on glycerol release and ${ }^{45} \mathrm{Ca}$ uptake by epididymal adipose tissue of lean and obese-hyperglycaemic mice

\begin{tabular}{|c|c|c|c|c|c|}
\hline & \multirow{2}{*}{$\begin{array}{l}\text { Concentration } \\
\mathrm{mol} / \mathrm{s}\end{array}$} & \multicolumn{2}{|l|}{ Lean mice } & \multicolumn{2}{|c|}{ Obese-hyperglycaemic mice } \\
\hline & & Lipolysis & ${ }^{45} \mathrm{Ca}$ uptake & Lipolysis & ${ }^{45} \mathrm{Ca}$ uptake \\
\hline Control & & $0.24 \pm 0.05$ & $28 \pm 5$ & $0.05 \pm 0.01$ & $31 \pm 5$ \\
\hline Isoproterenol & $10^{-5}$ & $1.08 \pm 0.08^{\mathrm{a}}$ & $108 \pm 13^{a}$ & $0.43 \pm 0.06^{\mathrm{a}}$ & $37 \pm 5$ \\
\hline ACTH & $10^{-5}$ & $1.22+0.09^{\mathrm{a}}$ & $123 \pm 15^{\mathrm{a}}$ & $0.47 \pm 0.06^{\mathrm{a}}$ & $33 \pm 5$ \\
\hline Theophylline & $5 \times 10^{-3}$ & $1.12 \pm 0.08^{\mathrm{a}}$ & $126 \pm 15^{a}$ & $0.41 \pm 0.06^{\mathrm{a}}$ & $41 \pm 6$ \\
\hline Dibutyryl cyclic AMP & $5 \times 10^{-3}$ & $1.20 \pm 0.09^{\mathrm{a}}$ & $117 \pm 12^{a}$ & $0.44 \pm 0.07^{\mathrm{a}}$ & $39 \pm 6$ \\
\hline
\end{tabular}

Epididymal adipose tissue fragments were preincubated for $30 \mathrm{~min}$ and incubated for $60 \mathrm{~min}$ in Krebs-Ringer bicarbonate buffer with 2.5 $\times 10^{-3} \mathrm{~mol} / \mathrm{l}$ calcium and $4 \mathrm{~g} / 100 \mathrm{ml}$ albumin. Results are expressed as $\mu \mathrm{mol}$ glycerol $/ 100 \mathrm{mg}$ fresh tissue $/ 60 \mathrm{~min}$ and as nmol ${ }^{45} \mathrm{Ca} / 100 \mathrm{mg}$ fresh tissue $/ 60 \mathrm{~min}$, and are means of 4 experiments \pm SEM. ${ }^{a} \mathrm{p}<0.05$ compared with control data

The net uptake of ${ }^{45} \mathrm{Ca}$ was not saturable within a $10^{-4}$ to $2.5 \times 10^{-3} \mathrm{~mol} / 1$ concentration range of extracellular calcium, even when the highest concentration tested was offered in the presence of $10^{-5} \mathrm{~mol} / 1$ isoproterenol or $5 \times 10^{-3} \mathrm{~mol} / 1$ theophylline (Fig. 3). On the other hand, a calcium concentration as low as $10^{-4} \mathrm{~mol} / 1$ gave almost all the stimulated activities obtained normally with a $2.5 \times$ $10^{-3} \mathrm{~mol} / \mathrm{l}$ concentration.

2,4-Dinitrophenol $\left(10^{-3} \mathrm{~mol} / \mathrm{l}\right)$ did not alter net ${ }^{45} \mathrm{Ca}$ uptake and basal lipolysis (Table 5), but it inhibited by one third the response to $10^{-5} \mathrm{~mol} / \mathrm{l}$ isoproterenol of net ${ }^{45} \mathrm{Ca}$ accumulation and glycerol release (Table 5).

The efflux of ${ }^{45} \mathrm{Ca}$ bound to cells or having entered intracellular spaces was recorded under EGTA treatment $\left(2 \times 10^{-3} \mathrm{~mol} / 1\right.$ in the absence of calcium), following a 60 minute preloading period in the presence of ${ }^{45} \mathrm{Ca}$.

Semilogarithmic plots (Fig. 4) of values uncorrected for the amount of ${ }^{45} \mathrm{Ca}$ still present in the interstitial space after the 1 minute prewashing show that a rapid initial fall in tissue ${ }^{45} \mathrm{Ca}$ was followed by a steadily decreasing rate in ${ }^{45} \mathrm{Ca}$ efflux. Thus the process was multiphasic. When corrected for the $\left[{ }^{3} \mathrm{H}\right]-$ inulin space (Fig. 4) the data show that a large proportion of the rapidly exchangeable pool with halftime of 1-2 minutes observed during the net uptake experiments (Fig. 1) was not revealed by the efflux curve. This was due to the 1 minute prewashing in the efflux method, which prevented the detection of most of such a short-lived $\mathrm{La}^{3+}$-displaceable interstitial pool. When added acutely, i. e. at the beginning of the efflux curve, isoproterenol had no apparent effect (data not shown), but when added together with ${ }^{45} \mathrm{Ca}$ during the 60 minute preloading period, the rate of efflux of ${ }^{45} \mathrm{Ca}$ that followed became apparently monoexponential (Fig. 4).

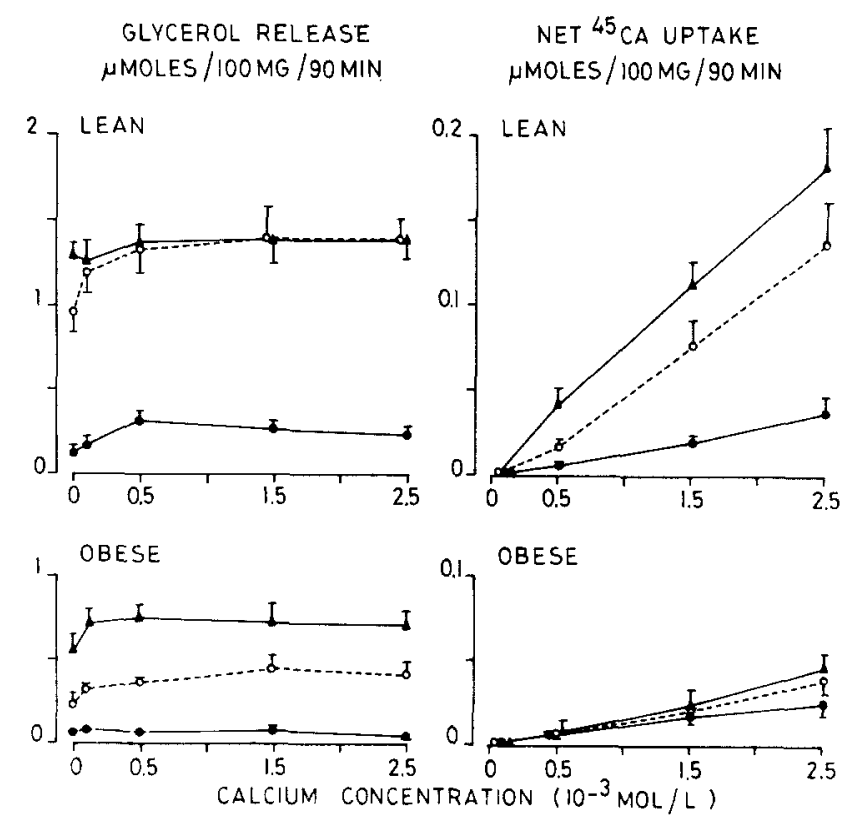

Fig. 3. Dose-response curves of calcium on glycerol release (left panels) and on the net uptake of ${ }^{45} \mathrm{Ca}$ (right panels) in epididymal adipose tissue of 3-4 month old normal (upper panels) and obesehyperglycaemic (lower panels) mice. Medium glycerol and ${ }^{45} \mathrm{Ca}$ uptake in excess of $\left[{ }^{3} \mathrm{H}\right]$-inulin space were determined after $90 \mathrm{~min}$ incubations in the absence $(\bullet)$ and in the presence of $10^{-5} \mathrm{~mol} / 1$ isoproterenol $(O)$ or $5 \times 10^{-3} \mathrm{~mol} / 1$ theophylline $(\mathbf{A})$. Values are means \pm SEM of 6 experiments

\section{Obese-Hyperglycaemic Mice}

In obese mice, basal and stimulated lipolysis were also linear for at least 90 minutes, but all values were approximately $65 \%$ lower than in lean controls (Fig. 1). Maximally effective concentrations [4] of isoproterenol $\left(10^{-5} \mathrm{~mol} / 1\right)$, ACTH $\left(10^{-5} \mathrm{~mol} / 1\right)$, and dibutyryl cyclic AMP $\left(5 \times 10^{-3} \mathrm{~mol} / \mathrm{l}\right)$ increased the release of glycerol 4 to 5 fold as in lean mice (Table 1). Also, with a medium free of calcium and enriched 
Table 5. Effects of 2,4-dinitrophenol on basal- and isoproterenol-stimulated lipolysis and ${ }^{45} \mathrm{Ca}$ uptake in epididymal adipose tissue of lean and obese-hyperglycaemic mice

\begin{tabular}{|c|c|c|c|c|c|}
\hline & \multirow{2}{*}{$\begin{array}{l}\text { Addition } \\
\mathrm{mol} / \mathrm{l}\end{array}$} & \multicolumn{2}{|l|}{ Lean mice } & \multicolumn{2}{|c|}{ Obese-hyperglycaemic mice } \\
\hline & & None & $\begin{array}{l}\text { Isoproterenol } \\
10^{-5} \mathrm{~mol} / 1\end{array}$ & None & $\begin{array}{l}\text { Isoproterenol } \\
10^{-5} \mathrm{~mol} / 1\end{array}$ \\
\hline \multirow[t]{2}{*}{ Lipolysis } & - & $0.13 \pm 0.03$ & $1.17 \pm 0.09$ & $0.07 \pm 0.02$ & $0.34 \pm 0.05$ \\
\hline & $2,4-\mathrm{DNP} 10^{-3}$ & $0.11 \pm 0.03$ & $0.76 \pm 0.07^{\mathrm{a}}$ & $0.08 \pm 0.02$ & $0.27 \pm 0.05$ \\
\hline \multirow[t]{2}{*}{${ }^{45} \mathrm{Ca}$ uptake } & - & $55 \pm 9$ & $114 \pm 15$ & $56 \pm 8$ & $57 \pm 7$ \\
\hline & $2,4-\mathrm{DNP} 10^{-3}$ & $52 \pm 7$ & $82 \pm 9^{a}$ & $51 \pm 8$ & $55 \pm 8$ \\
\hline
\end{tabular}

Epididymal adipose tissue fragments were preincubated for $30 \mathrm{~min}$ and incubated for $60 \mathrm{~min}$ in Krebs-Ringer bicarbonate buffer with ${ }^{45} \mathrm{Ca}$ and $\left[{ }^{3} \mathrm{H}\right]$-inulin, in the absence or in the presence of $10^{-3} \mathrm{~mol} / 12,4$-dinitrophenol. Results are expressed as $\mu \mathrm{mol}$ glycerol $/ 100 \mathrm{mg}$ fresh tissue $/ 60 \mathrm{~min}$ and as $\mathrm{nmol}{ }^{45} \mathrm{Ca} / 100 \mathrm{mg}$ fresh tissue $/ 60 \mathrm{~min}$ and are means $\pm \mathrm{SEM}$ of 9 experiments. ${ }^{a} \mathrm{p}<0.05$ compared with control data
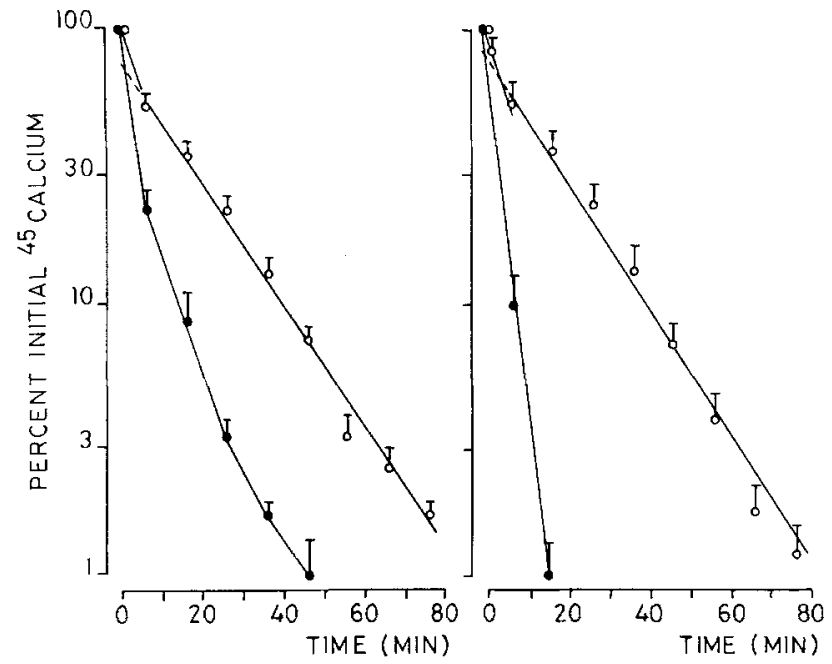

Fig. 4. Effects of $10^{-5} \mathrm{~mol} / \mathrm{l}$ isoproterenol on the time course of ${ }^{45} \mathrm{Ca}$ efflux from epididymal adipose tissue of 3-4 month old normal mice. Adipose tissue fragments were preincubated for 60 minutes in the presence of $2.5 \times 10^{-3} \mathrm{~mol} / \mathrm{l}^{45} \mathrm{Ca}$ and $\left[{ }^{3} \mathrm{H}\right]$-inulin, and in the absence $\left(\bullet\right.$ ) or presence $(O)$ of $10^{-5} \mathrm{~mol} / 1$ isoproterenol. They were then washed for $1 \mathrm{~min}$ and incubated without or with isoproterenol for $80 \mathrm{~min}$. The amount of ${ }^{45} \mathrm{Ca}$ was expressed as percentage of initial ${ }^{45} \mathrm{Ca}$ (left panel) or initial calcium (right panel) remaining present in excess of $\left[{ }^{3} \mathrm{H}\right]$-inulin space. Two or three phases can be identified. Each point represents the means \pm SEM of 3 experiments

with $2 \times 10^{-3} \mathrm{~mol} / 1 \mathrm{EGTA}$, the lipolytic response to $10^{-5} \mathrm{~mol} / 1 \mathrm{ACTH}$ was similarly abolished, and the response to isoproterenol was reduced by $40 \%$ whilst the lipolytic response to theophylline or dibutyryl cyclic AMP was unaffected (Table 1).

The net basal uptake of ${ }^{45} \mathrm{Ca}$ was identical to that observed in the adipose tissue of lean animals (Fig. 2). However, $2.5 \times 10^{-6} \mathrm{~mol} / 1$ isoproterenol and $5 \times 10^{-3} \mathrm{~mol} / 1$ theophylline were unable to increase this uptake (Fig. 2).

The concentration of isoproterenol giving an halfmaximal effect on glycerol release was approximately the same as in lean mice (Fig. 2). On the other hand, this agent was unable to stimulate the uptake of ${ }^{45} \mathrm{Ca}$ significantly (Fig. 2).

In the adipose tissue of obese mice, the lanthanum nondisplaceable ${ }^{45} \mathrm{Ca}$ was unaffected by the presence of $10^{-5} \mathrm{~mol} / \mathrm{l}$ isoproterenol and represented $12-13 \%$ and $35-36 \%$ of the total ${ }^{45} \mathrm{Ca}$ accumulated after 15 and 60 minutes, respectively (Table 3). A reduction in medium calcium concentration did not affect the rate of lipolysis (Fig. 3). The basal net uptake of ${ }^{45} \mathrm{Ca}$ increased in a dose-dependent manner (as in normal mice), but was not stimulated by $10^{-5} \mathrm{~mol} / 1$ isoproterenol or by $5 \times 10^{-3} \mathrm{~mol} / 1$ theophylline at any of the medium calcium concentrations tested (Fig. 3).

In the adipose tissue of obese mice, $10^{-3} \mathrm{~mol} / 1$ 2,4-dinitrophenol (Table 5) did not affect either glycerol release or net ${ }^{45} \mathrm{Ca}$ uptake.

\section{Effect of Preincubating Fat Pads and Fasting Lean and Obese Mice}

In adipose tissue fragments of normal mice, a 2 hour preincubation significantly increased basal lipolysis and net ${ }^{45} \mathrm{Ca}$ uptake (Table 6), but the effects of $10^{-5} \mathrm{~mol} / 1$ isoproterenol on both parameters were similar in absolute value to those observed in tissue without preincubation. The significant increase of basal- and isoproterenol-stimulated levels of cyclic AMP after a 1-2 hour preincubation probably reflected the time required for more effective cyclic AMP phosphodiesterase inhibition.

In adipose tissue fragments of obese mice, a onehour preincubation increased the basal- and isoproterenol-stimulated production of glycerol. This effect was confirmed after two hours of preincubation and in addition there was now a significant response of ${ }^{45} \mathrm{Ca}$ uptake to isoproterenol (Table 6). By contrast, preincubation did not increase basaland isoproterenol-stimulated levels of cyclic AMP.

In the adipose tissue of lean mice submitted to a 
Table 6. Effects of preincubation on lipolysis, ${ }^{44} \mathrm{Ca}$ uptake, and cyclic AMP levels in epididymal adipose tissue from lean and obesehyperglycaemic mice

\begin{tabular}{|c|c|c|c|c|c|c|c|}
\hline \multirow{2}{*}{$\begin{array}{l}\text { Prewashing } \\
\text { period hours }\end{array}$} & \multirow{2}{*}{$\begin{array}{l}\text { Isoproterenol } \\
10^{-5} \mathrm{~mol} / 1\end{array}$} & \multicolumn{3}{|l|}{ Lean mice } & \multicolumn{3}{|c|}{ Obese-hyperglycaemic mice } \\
\hline & & Lipolysis & ${ }^{45} \mathrm{Ca}$ uptake & Cyclic AMP & Lipolysis & ${ }^{45} \mathrm{Ca}$ uptake & Cyclic AMP \\
\hline 0 & 0 & $0.14 \pm 0.04$ & $20 \pm 7$ & $17 \pm 4$ & $0.07 \pm 0.04$ & $8 \pm 3$ & $10 \pm 2$ \\
\hline 0 & + & $1.38 \pm 0.10^{\mathrm{a}}$ & $139 \pm 33^{a}$ & $127 \pm 11^{\mathrm{a}}$ & $0.60 \pm 0.15^{\mathrm{a}}$ & $13 \pm 4$ & $35 \pm 9^{a}$ \\
\hline 1 & 0 & $0.15 \pm 0.08$ & $29 \pm 4$ & $28 \pm 5$ & $0.19 \pm 0.07$ & $20 \pm 3^{b}$ & $16 \pm 2$ \\
\hline 1 & + & $1.46 \pm 0.12^{\mathrm{a}}$ & $142 \pm 17^{\mathrm{a}}$ & $381 \pm 39^{a}$ & $0.97 \pm 0.10^{\mathrm{a}, \mathrm{b}}$ & $33 \pm 4^{b}$ & $27 \pm 3^{a}$ \\
\hline 2 & 0 & $0.53 \pm 0.16^{\mathrm{b}}$ & $48 \pm 10^{\mathrm{b}}$ & $28 \pm 7$ & $0.40 \pm 0.10^{\mathrm{b}}$ & $32 \pm 8^{b}$ & $15 \pm 1$ \\
\hline 2 & + & $1.21 \pm 0.16^{\mathrm{a}}$ & $129 \pm 8^{a}$ & $313 \pm 41^{a}$ & $1.07 \pm 0.28^{\mathrm{a}, \mathrm{b}}$ & $70 \pm 16^{\mathrm{a}, \mathrm{b}}$ & $26 \pm 4^{\mathrm{a}}$ \\
\hline
\end{tabular}

Epididymal adipose tissue fragments were either incubated directly or preincubated for one or two periods of 60 min in Krebs-Ringer bicarbonate buffer before incubation. Glycerol release was assayed after a $60 \mathrm{~min}$ incubation and expressed as $\mu \mathrm{mol} / 100 \mathrm{mg}$ fresh tissue. ${ }^{45} \mathrm{Ca}$ uptake was measured after a $60 \mathrm{~min}$ incubation period in the presence of ${ }^{45} \mathrm{Ca}$ and $\left[{ }^{3} \mathrm{H}\right]$-inulin and expressed as $\mathrm{nmol} / 100 \mathrm{mg}$ fresh tissue. Cyclic AMP levels in the tissue were assayed after a 7 min incubation and expressed as pmol $/ 100 \mathrm{mg}$ fresh tissue. $10^{-3} \mathrm{~mol} / 1$ theophylline was present during the preincubation and the incubation period. Results are means of 8 experiments $\pm S E M$. ${ }^{a} p<0.05$ compared with isoproterenol free medium. ${ }^{b} \mathrm{p}<0.05$ compared with no prewashing period

Table 7. Effects of fasting on lipolysis, ${ }^{45} \mathrm{Ca}$ uptake, and cyclic AMP levels in the epididymal adipose tissue from lean and obesehyperglycaemic mice

\begin{tabular}{|c|c|c|c|c|}
\hline & \multicolumn{2}{|l|}{ Lean mice } & \multicolumn{2}{|c|}{ Obese-hyperglycaemic mice } \\
\hline & Control & Isoproterenol $10^{-5} \mathrm{~mol} / 1$ & Control & Isoproterenol $10^{-5} \mathrm{~mol} / 1$ \\
\hline \multicolumn{5}{|c|}{ A/ Glycerol release } \\
\hline Fed & $0.25 \pm 0.03$ & $1.39 \pm 0.02$ & $0.10 \pm 0.01$ & $0.44 \pm 0.06$ \\
\hline Fasted & $0.47 \pm 0.06^{\mathrm{a}}$ & $1.35 \pm 0.07$ & $0.08 \pm 0.01$ & $0.36 \pm 0.03$ \\
\hline \multicolumn{5}{|c|}{ B/ Calcium uptake } \\
\hline Fed & $13 \pm 2$ & $81 \pm 20$ & $21 \pm 1$ & $30 \pm 5$ \\
\hline Fasted & $54 \pm 6^{a}$ & $150 \pm 65^{a}$ & $23 \pm 5$ & $32 \pm 5$ \\
\hline \multicolumn{5}{|c|}{ C/ Cyclic AMP } \\
\hline Fed & $20 \pm 1$ & $152 \pm 17$ & $20 \pm 5$ & $37 \pm 4$ \\
\hline Fasted & $28 \pm 5$ & $141 \pm 22$ & $12 \pm 4$ & $29 \pm 5$ \\
\hline
\end{tabular}

Lean and obese-hyperglycaemic mice were either fasted for $24 \mathrm{~h}$ or fed ad libitum. Epididymal adipose tissue was preincubated for $30 \mathrm{~min}$ in a Krebs-Ringer bicarbonate buffer. Glycerol release, ${ }^{45} \mathrm{Ca}$ uptake and cyclic AMP levels were assayed and expressed as detailed in legend of Table 6 . Results are means of 4 experiments \pm SEM. ${ }^{a} p<0.05$ compared with fed ad libitum data

24 hour fasting period (Table 7), in vitro basal lipolysis was increased by $86 \%$, basal cyclic AMP levels were unaltered and the basal uptake of ${ }^{45} \mathrm{Ca}$ increased by $232 \%$. The effects of $10^{-5} \mathrm{~mol} / \mathrm{l}$ isoproterenol on glycerol release and cyclic AMP levels were not affected, whereas that on net ${ }^{45} \mathrm{Ca}$ uptake was greater by $88 \%$ than in mice fed ad libitum. In obese animals a similar fasting period did not modify basal lipolysis, cyclic AMP levels or basal net ${ }^{45} \mathrm{Ca}$ uptake, either in the absence or the presence of $10^{-5} \mathrm{~mol} / 1$ isoproterenol.

\section{Discussion}

The use of intact tissue pieces instead of isolated fat cells avoids the problem of differential lysis of large fragile adipocytes in obese mice. This more "physiological" preparation involves the usual questions concerning slow diffusion in the interstitial space, the contribution of structures and cells other than fat cells, and the mode of expression of results collected from lean and obese animals $[3,12]$. Even if the present data could be expressed in terms of cellularity and/or subcellular water spaces rather than tissue weight, the major differences in the response to lipolytic agents in the adipose tissue of obese and non-obese mice would still be apparent.

\section{The Role of Calcium in Lipolysis in Lean Mice}

The lipolytic response to ACTH was highly dependent on the presence of extracellular calcium, whereas that induced by isoproterenol was less dependent, and that due to theophylline and dibutyryl cyclic AMP was unaffected by the absence of extracellular calcium (Tables 1 and 2). This variable sensitivity can be partially explained by the requirement for extracellular calcium of ACTH binding [20], whereas isoproterenol binding does not involve calcium. 
The modest effect of calcium deprivation (Fig. 3 and Table 1) on isoproterenol-induced lipolysis occurred in spite of there being a normal elevation of cyclic AMP levels. These results are mostly in accord with those of others $[6,7,8,11,21,22]$. They suggest that exogenous calcium acted as an additional messenger for isoproterenol at a site distal to the production of cyclic AMP. If this were true, then the normal lipolytic response obtained with theophylline or dibutyryl cyclic AMP in the presence of extracellular calcium might reflect the capacity of these agents to redistribute intracellular stores of calcium and compensate for the lack of exogenous calcium as previously suggested [11].

The reduction of ATP levels in response to isoproterenol and ACTH (Table 2) could be the consequence of uncoupling of oxidative phosphorylation by intracellular free fatty acids [17, 23]. After a period of calcium deprivation, ATP levels were not altered any more in response to lipolytic agents. However, glycerol release, cyclic AMP levels and ATP levels were again affected by readdition of calcium to the incubation medium (Table 2), consistent with data of Efendic et al. [11] on human adipose tissue, but not with those of Siddle and Hales [24] on isolated rat fat cells.

The kinetics of ${ }^{45} \mathrm{Ca}$ uptake suggested the presence of at least three types of calcium pool: $1 /$ the interstitial space which equilibrated with $\left[{ }^{3} \mathrm{H}\right]$-inulin with a half-time of 1-2 minutes only. At equilibrium this space was equivalent to about $17 \mu \mathrm{l} / 100 \mathrm{mg}$ wet weight (data not shown); $2 / \mathrm{a} \mathrm{La}^{3+}$-displaceable pool allowing rapid accumulation, independent of the preceding one [19], and presumably corresponding to the large binding capacity of negative charges located at the outer surface of plasma membranes (inter alia phospholipids and glycosaminoglycans [25]). Its extent was about 30 nanomoles/ $100 \mathrm{mg}$ wet weight; $3 /$ presumably intracellular pool(s) with slower filling. These pools were not $\mathrm{La}^{3+}$-displaceable (Table 3 ) and were related to energy production (Table 5). Their size was expanded 4-fold under isoproterenol and theophylline (Table 3 and Fig. 1).

From a methodological point of view, the precise estimate of ${ }^{45} \mathrm{Ca}$ uptake into the intracellular space depended on the accurate determination of the extracellular space. If the diffusion of $\left[{ }^{3} \mathrm{H}\right]$-inulin in the latter space was slower and/or less complete than that of ${ }^{45} \mathrm{Ca}$, an overestimation of the amount of ${ }^{45} \mathrm{Ca}$ gaining access to the intracellular compartments would be unavoidable. In the present experiments, $\left[{ }^{3} \mathrm{H}\right]$-inulin diffused in adipose tissue fragments of both normal and ob/ob mice with a half-time of $1 \mathrm{~min}$. An apparent steady state was reached after 15 min only (data not shown), suggesting increasing difficulty for this marker (with a molecular weight of around 5000) to gain access to some extracellular compartment(s) and/or a progressive oedema of the extracellular space [26]. Hence, the "superficial" calcium determined by the $\mathrm{La}^{3+}$-wash technique (Table 3) might correspond in part to an extracellular space not readily available to $\left[{ }^{3} \mathrm{H}\right]$-inulin.

If all the ${ }^{45} \mathrm{Ca}$ taken up by the slowly equilibrated pool(s) was present in an intracellular water space occupying $5 \%$ of adipose tissue fragments [26-28], the ${ }^{45} \mathrm{Ca}$ concentration would amount to $3 \mathrm{mmol} / \mathrm{l}$ and $12 \mathrm{mmol} / \mathrm{l}$ after $60 \mathrm{~min}$ without and with isoproterenol, respectively. When compared to the concentration in the incubation medium $(2.5 \mathrm{mmol} / \mathrm{l})$ and the estimated $0.1-1.0 \times 10^{-6} \mathrm{~mol} / \mathrm{l}$ cytosol free ionized calcium concentration in most cells, this illustrates the capacity of adipose cell structures for concentrating calcium. Among potential locations are the extensive endoplasmic reticulum of fat cells [29, 30] and mitochondria $[25,31]$, both of which store calcium in an ATP-dependent manner. The finding that $10^{-3} \mathrm{~mol} / 1$ 2,4-dinitrophenol impaired the isoproterenol-stimulated accumulation of ${ }^{45} \mathrm{Ca}$ as well as the lipolytic response (Table 5) is consistent with this mechanism and confirms previous data $[25,32]$.

In washout experiments, the tissue fragments could be almost totally depleted of their preloaded ${ }^{45} \mathrm{Ca}$ with EGTA (Fig. 4). The multiphasic ${ }^{45} \mathrm{Ca}$ efflux was a consequence of interstitial space, and of the retention of ${ }^{45} \mathrm{Ca}$ in intracellular exchangeable pools of increasing affinity. The one minute washing period preceding the recording of ${ }^{45} \mathrm{Ca}$ efflux sufficed to deplete the interstitial space of $33 \%$ of the $\left[{ }^{3} \mathrm{H}\right]$ inulin contained in this space at the beginning of the washout experiment (data not shown). The monoexponential efflux seen after 60 minutes of isoproterenol stimulation of ${ }^{45} \mathrm{Ca}$ uptake was a result of ${ }^{45} \mathrm{Ca}$ being then retained in a core of the tissue from which efflux was relatively slow.

We confirm previous data showing the stimulatory effects of lipolytic hormones on ${ }^{45} \mathrm{Ca}$ influx in tissue pieces $[9,10]$ and adipocytes $[6,33]$, but could not confirm the stimulation of ${ }^{45} \mathrm{Ca}$ efflux observed at late stages of washout curves [33]. In our experiments the apparent opposite effect, i. e. a decreased release of ${ }^{45} \mathrm{Ca}$ from fat tissue, is in doubt since the hormone effect on ${ }^{45} \mathrm{Ca}$ efflux was tested, before the equilibration with the isotope was complete (after 60 minutes: Figs. 1 and 4). At any rate, the net increase in the amount of ${ }^{45} \mathrm{Ca}$ accumulated after exposure to isoproterenol certainly reflected an increased rate of entry and not simply an increased exchange of calcium across plasma membranes. Any over-estimation of basal ${ }^{45} \mathrm{Ca}$ uptake tended to under-estimate the stimulatory effects of lipolytic agents on this parameter.

To define the intricate relationship between lipolysis and ${ }^{45} \mathrm{Ca}$ movements in the adipose tissue of lean mice, primary and secondary effects must be 
carefully delineated since cyclic AMP and calcium are interrelated intracellular messengers in a variety of cells [34]. First, it appears that the precipitation of calcium soaps of free fatty acids was not directly responsible for the calcium content of tissue. At low calcium concentration in the medium, lipolysis could indeed be stimulated maximally, although the net uptake of ${ }^{45} \mathrm{Ca}$ by the tissue was low (Fig. 3); furthermore, the isoproterenol concentration provoking half-maximal stimulation of lipolysis was three times lower than that required for half-maximal stimulation of ${ }^{45} \mathrm{Ca}$ uptake (Fig. 2).

On the other hand, the effects of theophylline and dibutyryl cyclic AMP (Table 1) suggest that intermediary events taking place before the release of free fatty acids, but beyond adenylate cyclase activation, induced a marked accumulation of cytosolic calcium.

In fact, calcium movements in both directions appeared capable of regulating the lipolytic process: a/ The availability of exogenous calcium was required for the specific action of ACTH (Tables 1 and 2 , and ref. [20], for an optimal response to isoproterenol (Tables 1 and 2, and refs. [6, 8, 11, 21, $22]$ ), and probably for lipolytic steps beyond cyclic AMP accumulation (Table 2 and ref. [6]); b/ The mobilisation of intracellular calcium [35] might also contribute to an optimal lipolytic response to isoproterenol (Tables 1 and 2), and cover calcium requirements in the presence of theophylline or dibutyryl cyclic AMP (Table 1) as previously shown $[8,10]$.

\section{Lipolysis-Calcium Relationship in the Adipose Tissue of Obese-Hyperglycaemic Mice}

The poor lipolytic response of the adipose tissue of obese mice has been related to a defect in adenylate cyclase activity $[3,12]$. The present data imply that an alteration in calcium movements might also contribute to reduce a futile cycle of lipolysis and reesterification in this tissue. At equilibrium ${ }^{45} \mathrm{Ca}$ was distributed in the extracellular space $(9 \mu \mathrm{l} / 100 \mathrm{mg}$ wet weight: data not shown) and a mostly $\mathrm{La}^{3+}$-displaceable space of normal size (Fig. 1). However, unlike in normal mice, the entry of ${ }^{45} \mathrm{Ca}$ was not stimulated by isoproterenol and by dibutyryl cyclic AMP (Figs. 1-3; Table 3). In addition the stimulation of ${ }^{45} \mathrm{Ca}$ uptake, in response to an increase in calcium concentration from 0.1 to $2.5 \mathrm{mmol} / 1$, was lower than in lean mice (Fig. 3).

These observations stress again that there was no direct relationship between lipolysis and the net uptake of ${ }^{45} \mathrm{Ca}$, i. e. the latter does not result directly from the presence and concentration of free fatty acids. More importantly they allow an extension to adipose tissue of the hypothesis [36] of a defect in calcium movements in the liver of ob/ob mice. These authors observed that hepatic glycogen breakdown was poorly stimulated by vasopressin. Since vasopressin is thought to act on glycogenolysis by modifying the movements of calcium in the cell [36], alterations in hepatic alcium handling might contribute to the syndrome. The observation [37] of a defective $\left(\mathrm{Na}^{+}+\mathrm{K}^{+}\right)$-ATPase activity in plasma membranes of liver and kidney suggests that more than one alteration in the control of ionic distribution are present in obese mice.

Attempts to correct the present alterations were only partly successful. The lower in vitro sensitivity of lipolysis to isoproterenol was not increased by a one day fast, but was fully restored by a 1-2 hour preincubation in a glucose-free buffer, as previously shown [38]. Furthermore, the net calcium uptake became sensitive and the cyclic AMP elevation remained refractory to isoproterenol after preincubation (Table 7). This is in line with previous data showing that a preincubation period also increased the response to insulin of both catecholamine-stimulated lipolysis [38] and glucose uptake [39]. One possible explanation of these results would be that the removal of an inhibitor present in excess in the adipose tissue of obese mice and acting beyond adenylate cyclase contributed to this recovery. Insulin saturating adipose tissue, because of the high circulating insulin level, might not represent this labile unidentified inhibitor, considering the reduced insulin-binding capacity of the tissue [40] and the failure of an anti-insulin serum to correct in vitro the depressed response of lipolysis to epinephrine or theophylline [41].

Acknowledgements. J. P. Dehaye is Aspirant du Fonds National de la Recherche Scientifique (Belgium). This work was supported by Grant $n^{\circ} 20,403$ from the Fonds de la Recherche Scientifique Médicale (Belgium). The authors are indebted to Dr. J. Hutton and Mrs. J. Ballinckx for help in the preparation of the manuscript and to Dr. A. Daubresse (Ciba-Geigy, Brussels) for the gift of ACTH (synthetic corticotropin 1-24).

\section{References}

1. Belfrage, P., Jergil, B., Strålfors, P., Tornqvist, H.: Hormonesensitive lipase of rat adipose tissue: identification and some properties of the enzyme protein. FEBS Lett. 75, 259-264 (1977)

2. Schwabe, U., Ebert, R.: Different effects of lipolytic hormones and phosphodiesterase inhibitors on cyclic $3^{\prime}, 5^{\prime}$-AMP levels in isolated fat cells. Naunyn Schmiedebergs Arch. Pharmacol. 274, 287-298 (1972)

3. Dehaye, J.P., Winand, J., Christophe, J.: Lipolysis and cyclic AMP levels in epididymal adipose tissue of obese-hyperglycaemic mice. Diabetologia 13, 553-561 (1977)

4. Fain, J. N.: Biochemical aspects of drug and hormone action on adipose tissue. Pharmacol. Rev. 25, 67-118 (1973)

5. Siddle, K., Hales, C. N.: The action of local anaesthetics on lipolysis and on adenosine $3^{\prime}, 5^{\prime}$-cyclic monophosphate content in isolated rat fat cells. Biochem. J. 142, 345-351 (1974) 
6. Schimmel, R. J.: Calcium antagonists and lipolysis in isolated rat epididymal adipocytes: effects of tetracaine, manganese, cobaltous and lanthanum ions and D600. Horm. Metab. Res. 10, 128-134 (1978)

7. Schimmel, R. J.: The influence of extracellular calcium ion on hormone activated lipolysis. Biochim. Biophys. Acta 326, 272-278 (1973)

8. Mosinger, B., Vaughan, M.: Effects of electrolytes on epinephrine stimulated lipolysis in adipose tissue in vitro. Biochim. Biophys. Acta 144, 556-568 (1967)

9. Akgün, S., Rudman, D.: Relationships between mobilization of free fatty acids from adipose tissue, and the concentration of calcium in the extracellular fluid and in the tissue. Endocrinology 84, 926-930 (1969)

10. Alm, B., Efendić, S., Löw, H.: Effect of lipolytic and antilipolytic agents on the uptake of ${ }^{47}$ calcium into rat adipose tissue in vitro. Horm. Metab. Res. 2, 142-146 (1970)

11. Efendic, S., Alm, B., Löw, H.: Effects of $\mathrm{Ca}^{++}$on lipolysis in human omental adipose tissue in vitro. Horm. Metab. Res. 2, 287-291 (1970)

12. Dehaye, J.P., Winand, J., Christophe, J.: Adenylate cyclase activity in the epididymal adipose tissue from obese-hyperglycaemic mice. Diabetologia 15, 45-51 (1978)

13. Shepherd, R. E., Malbon, C. C., Smith, C. J., Fain, J. N.: Lipolysis and adenosine $3^{\prime}: 5^{\prime}$-monophosphate metabolism in isolated white fat cells from genetically obese-hyperglycemic mice (ob/ob). J. Biol. Chem. 252, 7243-7248 (1977)

14. Dehaye, J. P., Winand, J., Christophe, J.: Effect of lipolytic agents on calcium uptake in the epididymal adipose tissue of obese-hyperglycemic mice and their lean littermates. Arch. Int. Physiol. Biochim. 85, 396-398 (1977)

15. Wieland, O.: Eine enzymatische Methode zur Bestimmung von Glycerol. Biochem. Z. 329, 313-319 (1957)

16. Gilman, A. G.: A protein binding assay for adenosine $3^{\prime}, 5^{\prime}-$ cyclic monophosphate. Proc. Natl. Acad. Sci. USA 67, 305-312 (1970)

17. Bihler, I., Jeanrenaud, B.: ATP content of isolated fat cells. Effects of insulin, ouabain and lipolytic agents. Biochim. Biophys. Acta 202, 496-506 (1970)

18. Van Breemen, C., Farinas, B. R., Casteels, R., Berba, P., Wuytack, F., Deth, R. Factors controlling cytoplasmic $\mathrm{Ca}^{2+}$ concentration. Proc. R. Soc. Lond. [Biol.] 265, 57-71 (1973)

19. Hellman, B.: Calcium and pancreatic $\beta$-cell function. 3. Validity of the $\mathrm{La}^{3+}$-wash technique for discriminating between superficial and intracellular ${ }^{45} \mathrm{Ca}$. Biochim. Biophys. Acta 540, 534-542 (1978)

20. Katocs, A. S., Jr., Largis, E. E., Allen, D. O.: Role of $\mathrm{Ca}^{2+}$ in adrenocorticotropic hormone-stimulated lipolysis in the perifused fat cell system. J. Biol. Chem. 249, 2000-2004 (1974)

21. Khoo, J. C., Steinberg, D., Thompson, B., Magee, S. E.: Hormonal regulation of adipocyte enzymes. The effects of epinephrine and insulin on the control of lipase, phosphorylase kinase, phosphorylase and glycogen synthetase. J. Biol. Chem. 248, 3823-3830 (1973)

22. Fain, J. N.: Inhibition of adenosine cyclic $3^{\prime}, 5^{\prime}$-monophosphate accumulation in fat cells by adenosine $\mathrm{N}^{6}$-(phenyl-isopropyl) adenosine and related compounds. Mol. Pharmacol.9, 595-604 (1973)

23. Angel, A., Desai, K. S., Halperin, M. L.: Reduction in adipocyte ATP by lipolytic agents: relation to intracellular free fatty acid accumulation. J. Lipid Res. 12, 203-213 (1971)

24. Siddle, K., Hales, C. N.: Calcium and lipolysis in adipose tissue: effects of ethanedioxybis-(ethylamine)tetra-acetate (EGTA) and ionophore A23187. Biochem. Soc. Trans. 5, 959-962 (1977)

25. Martin, B. R., Clausen, T., Gliemann, J.: Relationships between the exchange of calcium and phosphate in isolated fatcells. Biochem. J. 152, 121-129 (1975)
26. Winand, J., Christophe, $\mathbf{J}$.: Métabolisme in vitro du tissu adipeux. IV. Relations entre les espaces aqueux du tissu adipeux épididymaire du rat et l'albumine sézique. Bull. Soc. Chim. Biol. 49, 299-315 (1967)

27. Crofford, O. B., Renold, A. E.: Glucose uptake by incubated rat epididymal adipose tissue. Rate-limiting steps and site of insulin action. J. Biol. Chem. 240, 14-21 (1965)

28. Gliemann, J., Osterlind, K., Vinten, J., Gammeltoft, S.: A procedure for measurement of distribution spaces in isolated fat cells. Biochim. Biophys. Acta 286, 1-9 (1972)

29. Bruns, D. E., McDonald, J. M., Jarett, L.: Energy-dependent calcium transport in endoplasmic reticulum of adipocytes. J. Biol. Chem. 251, 7191-7197 (1976)

30. Hales, C. N., Luzio, J. P., Chandler, J. A., Herman, L.: Localization of calcium in the smooth endoplasmic reticulum of rat isolated fat cells. J. Cell Sci. 15, 1-15 (1974)

31. Severson, D. L., Denton, R. M., Bridges, B. J., Randle, P. I.: Exchangeable and total calcium pools in mitochondria of rat epididymal fat-pads and isolated fat-cells. Biochem. J. 154, 209-223 (1976)

32. Clausen, T.: Electrolytes and the hormonal control of organic metabolism in adipocytes. In: Adipose tissue. Regulation and metabolic functions. Jeanrenaud, B., Hepp D. (Eds.), pp. 66-70. New York, London: Academic Press 1970

33. Hope-Gill, Kissebah, A., Tulloch, B., Clarke, P., Vydelingum, N., Fraser, T. R.: The effects of insulin on adipocyte calcium flux and the interaction with the effects of dibutyryl cyclic AMP and adrenaline. Horm. Metab. Res. 7, 195-196 (1975)

34. Rasmussen, H.: Cell communication, calcium ion, and cyclic adenosine monophosphate. Science 170, 404-412 (1970)

35. Hems, D. A., Ma, G. Y.: Resistance to hepatic action of vasopressin in genetically obese (ob/ob) mice. Biochem. J. 160, 23-28 (1976)

36. Keppens, S., Vandenheede, J. R., De Wulf, H.: On the role of calcium as second messenger in liver for the hormonally induced activation of glycogen phosphorylase. Biochim. Biophys. Acta 496, 448-457 (1977)

37. York, D. A., Bray, G. A., Yukimura, Y.: An enzymatic defect in the obese $(\mathrm{ob} / \mathrm{ob})$ mouse: Loss of thyroid-induced sodiumand potassium-dependent adenosinetriphosphatase. Proc. Natl. Acad. Sci. USA 75, 477-481 (1978)

38. Clarke, P. V., Kissebah, A. H., Hope-Gill, H., Vydelingum, N., Tulloch, B., Fraser, T. R.: The role of calcium in insulin action. IV. Mechanism of insulin resistance in adipose tissue of obese (ob/ob) mice and old Wistar rats. Eur. J. Clin. Invest. 5, 351-358 (1975)

39. Winand, J., Christophe, J.: Effect of preincubation on the metabolism of $\left[\mathrm{U}-{ }^{14} \mathrm{C}\right]$ glucose and $\left[{ }^{3} \mathrm{H}\right] \mathrm{H}_{2} \mathrm{O}$ by the epididymal adipose tissue of obese-hyperglycemic (ob/ob) Bar Harbor mice. Arch. Int. Physiol. Biochim. 84, 207-208 (1976)

40. Freychet, P., Laudat, M. H., Laudat, P., Rosselin, G., Kahn, C. R., Gorden, P., Roth, J.: Impairment of insulin binding to the fat cell plasma membrane in the obese-hyperglycemic mouse. FEBS Lett. 25, 339-342 (1972)

41. Yen, T. T., Steinmetz, J.A.: Lipolysis of genetically obese and/or hyperglycemic mice with reference to insulin response of adipose tissue. Horm. Metab. Res. 4, 331-337 (1972)

Received: September 19, 1978,

and in revised form: February 21, 1979

Prof. J. Christophe

Department of Biochemistry

Medical School

U. L. B.

rue Evers, 2

B-1000 Brussels, Belgium 